\title{
Endogenous Circulating DNA in Systemic Lupus Erythematosus Occurrence as Multimeric Complexes Bound to Histone
}

Peter M. Rumore and Charles R. Steinman

The Department of Medicine, Division of Rheumatology, The State University of New York, Health Science Center at Brooklyn, Brooklyn, New York 11203

\begin{abstract}
Little is known about endogenous systemic lupus erythematosus (SLE) plasma DNA even though it is the presumed precursor of DNA-containing immune complexes, thought to play a central role in lupus glomerulonephritis. DNA purified from SLE plasma formed discrete bands, corresponding to sizes of about $150-200,400,600$, and $800 \mathrm{bp}$, closely resembling the characteristic 200 bp "ladder" found with oligonucleosomal (ON) DNA. By radiolabeling DNA while in whole plasma, the very small amounts present could be further characterized. All of 24 such specimens formed two or more discrete bands on $6 \%$ PAGE. Detergent treatment of plasma resulted in a DNA migration pattern similar to that of purified DNA, suggesting disruption of DNA-protein complexes. DNA purified from authentic $O N$ and detergent-treated $O N$ behaved similarly. A significant portion of DNA, labeled in SLE plasma could be specifically immunoprecipitated with monoclonal antihistone antibody as was the case with $\mathrm{ON}$. These immunoprecipitates, when redissolved, exhibited the expected size distribution upon PAGE. It is concluded that DNA in SLE plasma occurs as a series of multimeric complexes, at least a portion of which is noncovalently bound to histone. These results are consistent with an ON-like structure for SLE plasma DNA as had been suggested by theoretical considerations and may have important implications for its immunologic behavior in SLE and perhaps other disorders. (J. Clin. Invest. 1990. 86:69-74.) Key words: nucleosome $\bullet$ immune complexes $\bullet$ autoimmunity $\bullet$ glomerulonephritis • apoptosis
\end{abstract}

\section{Introduction}

DNA-containing immune complexes are believed to have a central causal role in lupus glomerulonephritis (1). The proximate source of the DNA component of these complexes, presumed to be plasma DNA, has been difficult to study, in part because of the low concentrations present in most SLE specimens (2-4).

Previous studies have shown SLE plasma DNA to be of low molecular weight, largely double-stranded, but with single-

A preliminary report of this work has appeared in abstract form in 1988. (Clin. Res. 36:537a.)

Address reprint requests to Dr. Steinman, Division of Rheumatology, The State University of New York, Health Science Center at Brooklyn, Box 42, 450 Clarkson Avenue, Brooklyn, NY 11203.

Received for publication 15 September 1988 and in revised form 18 September 1989.

J. Clin. Invest.

(c) The American Society for Clinical Investigation, Inc.

0021-9738/90/07/0069/06 \$2.00

Volume 86, July 1990, 69-74 stranded regions, and to contain nucleotide base sequences most or all of which are present in the human genome (3-6).

The present results indicate that DNA in SLE plasma exhibits structural characteristics similar to those of oligonucleosomes as would be consistent with its having been derived from these macromolecular complexes with retention of some of their structural features. Such an oligonucleosomal (ON) ${ }^{1}$ like structure might have important implications for its apparent role in SLE, particularly with regard to its immunologic behavior and to its cellular origins.

\section{Methods}

Patients and plasma specimens. Patients with SLE were selected for having persistently circulating immunoprecipitable dsDNA associated with active systemic vasculitis and/or CNS involvement as described (7). All fulfilled American Rheumatism Association diagnostic criteria for SLE (8). Plasma was handled as previously described (7) and stored below $-20^{\circ} \mathrm{C}$. Storage of these EDTA-containing specimens had no discernable effect on the results obtained. Plasma specimens were in activated at $56^{\circ} \mathrm{C}$ for $30 \mathrm{~min}$ and dialyzed overnight in $10 \mathrm{mM}$ Tris$\mathrm{HCl}, 1 \mathrm{mM}$ EDTA, pH 8.0 (TE). Omission of heat inactivation did not alter the results. Plasma DNA concentrations were between 20 and 300 $\mathrm{ng} / \mathrm{ml}(9)$. None exhibited increased anti-dsDNA (10), as has generally been found to be the case in such patients (7).

DNA and oligonucleosomes. Plasma DNA was purified by a modification of a previous method that was not size selective and gave $30-80 \%$ recovery (4). Plasma, $100 \mu \mathrm{l}$, was made $0.1 \mathrm{M}$ in Tris-HCl, pH 8.0, $20 \mathrm{mM}$ in EDTA, $1 \mathrm{M}$ in sodium perchlorate, and $1 \%$ in SDS. Proteinase K (Sigma Chemical Co., St. Louis, MO), $100 \mu \mathrm{g} / \mathrm{ml}$, was then added and the mixture incubated at $55^{\circ} \mathrm{C}$ for $2 \mathrm{~h}$. It was then extracted sequentially, as described elsewhere (11), with phenol, phenol-chloroform and chloroform, precipitated with ethanol and dissolved in $50 \mu$ l of TE. Human placental DNA (Sigma Chemical Co.) was denatured at $0.5 \mathrm{mg} / \mathrm{ml}$ in TE by boiling for $10 \mathrm{~min}$ followed by rapid cooling. DNAase digestion of radiolabeled plasma or $\mathrm{ON}$ was with DNAase I, $50 \mu \mathrm{g} / \mathrm{ml}$, at $37^{\circ} \mathrm{C}$ for $30 \mathrm{~min}$. In controls, the DNAase I was heat inactivated at $100^{\circ} \mathrm{C}$ for $10 \mathrm{~min}$. ON were prepared from chick erythrocytes (Whittaker Bioproducts, Walkersville, MD), by digestion of nuclei with micrococcal nuclease and stored at $-20^{\circ} \mathrm{C}$ in the presence of phenylmethylsulfonylfluoride as a protease inhibitor (12). Anti-DNA reactions were carried out with antisera obtained from three patients with SLE, and were all capable of precipitating dsDNA (9). $10 \mu \mathrm{l}$ of ON or DNA in plasma were incubated with $20 \mu \mathrm{l}$ of antiserum at $37^{\circ} \mathrm{C}$ for $30 \mathrm{~min}$ and then at $4^{\circ} \mathrm{C}$ for $1 \mathrm{~h}$, followed by centrifugation at $13,600 \mathrm{~g}$ for $15 \mathrm{~min}$. $20 \mu \mathrm{l}$ of supernatant, treated as before with SDS, were then examined by PAGE. Controls employed antiserum that had been absorbed with $25 \mu \mathrm{g} / \mathrm{ml}$ each of native and heat-denatured human placental DNA at $37^{\circ} \mathrm{C}$ for $30 \mathrm{~min}$ and $4^{\circ} \mathrm{C}$ overnight.

Radiolabeling and PAGE. Purified DNA was radiolabeled by nicktranslation as described elsewhere (11), using $\left[\alpha-{ }^{32} \mathrm{P}\right] \mathrm{dCTP}$ from New

1. Abbreviations used in this paper: $\mathrm{ON}$, oligonucleosome; TE, TrisEDTA buffer. 
England Nuclear (Boston, MA), 2-3,000 Ci/mM. DNA in dialyzed plasma and in $\mathrm{ON}$ was labeled in exactly the same manner except that DNAase digestion could be omitted for plasma, apparently because it is sufficiently nicked in vivo. PAGE was on $6 \%$ polyacrylamide in 89 mM Tris, $89 \mathrm{mM}$ boric acid, 2 mM EDTA, pH 8.0 (TBE) (11). In a typical experiment, each sample lane contained the DNA derived from $10 \mu$ original plasma. DNA size standards consisted of a Hae III digest of phi-X DNA (New England Biolabs, Beverly, MA). Radiolabeling of standards was either by nick translation or by 5 -end-labeling (11). Where indicated, labeled specimens were treated with $1 \%$ SDS for $>10$ min at $20^{\circ} \mathrm{C}$. Each sample lane contained $10 \mu \mathrm{l}$ of a $100-\mu l$ labeling reaction mixture containing $80 \mu \mathrm{l}$ of plasma or ON. Autoradiography was at $4^{\circ} \mathrm{C}$ on Kodak X-Omat AR film (Eastman Kodak Co., Rochester, NY). Exposure times were varied to allow optimum resolution of bands so that band intensities are not necessarily comparable among different experiments.

Experiments to examine the mobilities of plasma DNA bands upon re-electrophoresis were done after electroelution of individual excised bands as described elsewhere (11). The eluate was then reconcentrated by vacuum dialysis using collodion bags (Schleicher and Schuell, Inc., Keene, NH), following the directions of the supplier.

Antihistone experiments. A monoclonal antihistone antibody reactive with a trypsin-sensitive epitope accessible in oligonucleosomes and, as control, a monoclonal antiacetylcholinesterase antibody of the same isotype (catalogue No. MAB052 and MAB304, respectively) were purchased from Chemicon International, Inc. (El Segundo, CA). The reactivity of the antihistone antibody with a trypsin-sensitive epitope on $\mathrm{ON}$ was confirmed in preliminary experiments where labeled ON were incubated at $37^{\circ} \mathrm{C}$ for $30 \mathrm{~min}$ with 10 or $100 \mu \mathrm{g} / \mathrm{ml}$ trypsin (Sigma) in the presence or absence of a twofold excess of soybean trypsin inhibitor (Sigma).

Antihistone precipitation experiments were performed on duplicate specimens of five SLE plasmas and an ON preparation. A mixture containing $10 \mu \mathrm{l}$ of plasma containing labeled DNA (generally containing between 50,000 and $150,000 \mathrm{cpm}$ ) or nucleosomal DNA, $5 \mu \mathrm{l}$ of either the monoclonal antihistone or the anticholinesterase control antibody, $5 \mu \mathrm{l}$ of $0.15 \mathrm{M}$ sodium chloride, $0.01 \mathrm{M}$ sodium phosphate, pH 7.2 (PBS) and $1 \mu \mathrm{l}$ of salmon sperm DNA (Sigma), $10 \mathrm{mg} / \mathrm{ml}$ in TE, was incubated at $37^{\circ} \mathrm{C}$ for $45 \mathrm{~min}$. Then $5 \mu$ lof normal mouse serum (Sigma), diluted 1:5 in PBS was added and, after incubating at $37^{\circ} \mathrm{C}$ for $15 \mathrm{~min}, 15 \mu \mathrm{l}$ of rabbit anti-mouse IgG (Sigma), $2 \mathrm{mg} / \mathrm{ml}$ in PBS, was added followed by incubation at $37^{\circ} \mathrm{C}$ for $60 \mathrm{~min}$ and at $4^{\circ} \mathrm{C}$ overnight. The mixture was then centrifuged at $13,600 \mathrm{~g}$ for $15 \mathrm{~min}$, the supernatant was removed, and the precipitate washed twice with $20 \mu \mathrm{l}$ PBS. $50 \mu$ l of TE containing $1 \%$ SDS was then added to the washed precipitate and the mixture incubated at $100^{\circ} \mathrm{C}$ for $1 \mathrm{~h}$ during which it dissolved. The duplicate sets of specimens were then examined both by electrophoresis on $6 \%$ polyacrylamide in $1 \%$ SDS and TBE and by TCA precipitation and counting in a scintillation counter (Packard Tri-Carb; model 300C) with a background of $29 \mathrm{cpm}$, which was subtracted from the resulting counts. An additional set of control experiments was performed using the same procedure and starting with the same five SLE plasmas and preparation of ON but with exogenous labeled DNA in place of labeled endogenous plasma DNA. This exogenous DNA consisted of electrophoretically purified 190-310 bp Hae III fragments of phi-X DNA that had been 5'-end-labeled to an approximate specific activity of $1.8 \times 10^{7} \mathrm{cpm} / \mu \mathrm{g}$.

\section{Results}

DNA purified from SLE plasma exhibits multiple discrete size distributions. DNA, first purified from whole SLE plasma and then radiolabeled, generally demonstrated four bands on PAGE with sizes corresponding to $\sim 150-200,400,600$, and 800 bp (Fig. 1). With some specimens the separation between the 600 - and $800-$ bp bands was indistinct so that the two blended together. Most or all of the radioactivity appeared to

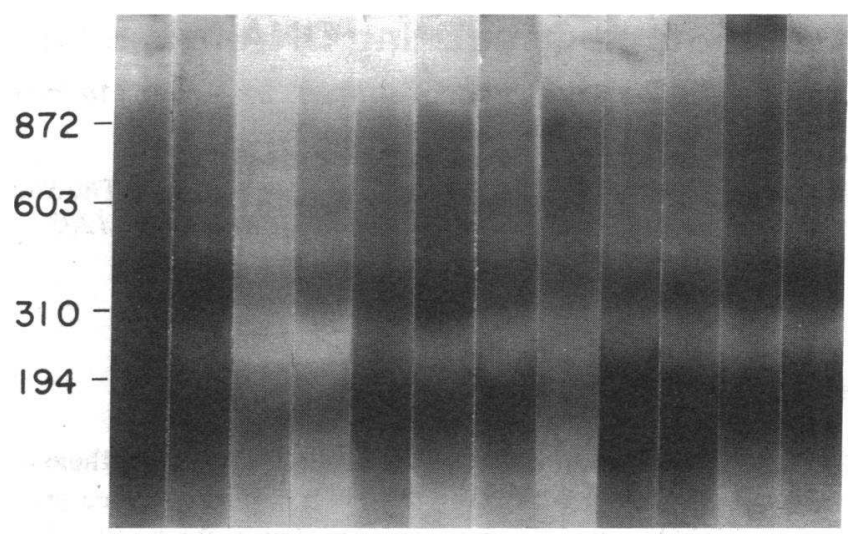

Figure 1. DNA extracted from a representative group of 12 SLE plasma specimens, labeled by nick-translation and separated by PAGE. At the left are locations of DNA size markers in base pairs. In most cases the bands migrating at $\sim 150-200$ bp is the strongest. Bands at $\sim 400,600$, and 800 bp are also visible although the separation between the 600 - and 800 -bp bands is frequently indistinct.

be associated with one of these bands. Small amounts of low molecular weight radioactivity were variably seen at the bottoms of some lanes and represented molecules $\sim 50 \mathrm{bp}$ long or less. Most of the radioactivity was usually in the 150-200-bp band with progressively less in each of the slower bands. All of 20 DNA specimens that were examined were similar.

DNA radiolabeled in plasma forms discrete bands on $P A G E$. PAGE of 24 DNA specimens labeled in whole plasma consistently revealed two prominent bands on autoradiography (Fig. $2 \mathrm{~A}$ ). A slower, faint band was also frequently seen. Bands of other mobilities were also seen, but infrequently. Autoradiographic intensity was usually higher for the faster bands.

A variable amount of radioactivity failed to enter the gel. Treatment with SDS largely eliminated this but also changed the mobilities of the bands, as will be discussed. To confirm that the labeled material was in fact DNA, it was shown that, in a subgroup of specimens, digestion with DNAase I, but not inactivated DNAase I, eliminated the radioactive bands. Also, incubation with each of three different anti-dsDNA-containing antisera removed $>90 \%$ of the radioactivity from the gel. Prior absorption of the antisera with DNA abolished this activity.

The fastest DNA band in plasma, which also was the most intense, migrated more slowly than did the fastest band in the DNA extracted from plasma (Fig. $2 \mathrm{~B}$ ), consistent with the interpretation that, in plasma, the migration of this DNA species had been retarded, presumably by binding to protein.

Purified DNA that had first been radiolabeled while in whole plasma and then extracted gave a banding pattern on PAGE similar to that of DNA labeled after extraction from plasma. Thus, each of the molecular species seen in DNA labeled after purification from plasma was accessible to the labeling reagents before extraction. Also, no molecular species was labeled in plasma that was not also labeled after extraction. To explore the effect of plasma protein binding on the gel mobility of DNA, an attempt was made to add purified, labeled plasma DNA back to unlabeled plasma. This resulted primarily in radioactive material that failed to enter the gel, presumably due to aggregates formed by nonspecific electro- 


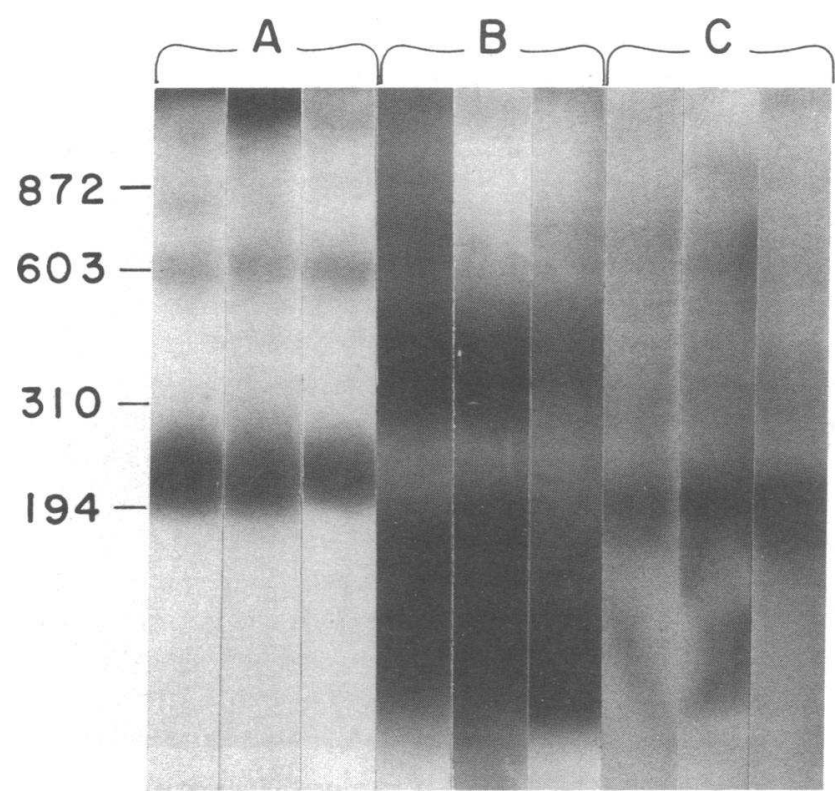

Figure 2. Autoradiographic banding pattern of SLE plasma DNA on PAGE. Specimens from three patients are shown in each of the three panels, $A, B$ and $C$. DNA marker locations are indicated at the left as in Fig. 1. $(A)$ Whole plasma containing labeled DNA, $10 \mu \mathrm{l}$ per well. Bands migrating near the 603- and 194-bp markers were uniformly observed. Also, a band just ahead of the 872-bp marker was occasionally seen as in the specimen at the far left. $(B)$ DNA extracted from plasma and then radiolabeled, similar to Fig. 1 and shown here for comparison. $(C)$ DNA in plasma, labeled as before but with $1 \%$ SDS added. The banding pattern is generally similar to that seen with DNA extracted from plasma. Autoradiographic signals extending irregularly toward the bottoms of the lanes are artifactual.

static interaction with plasma components. Incubation at $37^{\circ} \mathrm{C}$ for $30 \mathrm{~min}$ did not alter this. A similar result was obtained when purified plasma DNA was replaced by a labeled Hae III digest of phi-X DNA.

SDS treatment. Treatment of plasma with SDS resulted in a DNA banding pattern that was similar to that of DNA extracted from plasma (Fig. $2 C$ ). This suggested that SDS treatment largely released plasma DNA from association with retarding molecules and allowed it to migrate in plasma essentially as free DNA. The mobility of uncomplexed control DNA, added to SDS-treated plasma, migrated no differently from DNA in buffer alone. SDS treatment gave more homogeneous DNA bands in plasma than were seen with purified DNA, probably because of damage during purification.

Comparison with $O N$. Radiolabeled ON behaved on PAGE as shown in Fig. $3 \mathrm{~A}$. Attempts to examine the mobility of labeled ON added to plasma resulted in most or all of the added radiolabel failing to enter the gel and remaining as aggregates at the origin. In some experiments a faint band could be observed to enter the gel but this was not reproducible. This observation was similar to that made after addition of purified labeled DNA to plasma, just described, and is assumed also to be due to aggregate formation with plasma proteins. Replacing plasma with serum, incubation of plasma-ON mixtures at $37^{\circ} \mathrm{C}$ for as long as $16 \mathrm{~h}$ and predigestion of $\mathrm{ON}$ with trypsin all failed to alter this result. In buffer, $O N$ gave a series of bands migrating more slowly than did DNA in plasma. Partial proteolysis with trypsin increased their mobility, but they still

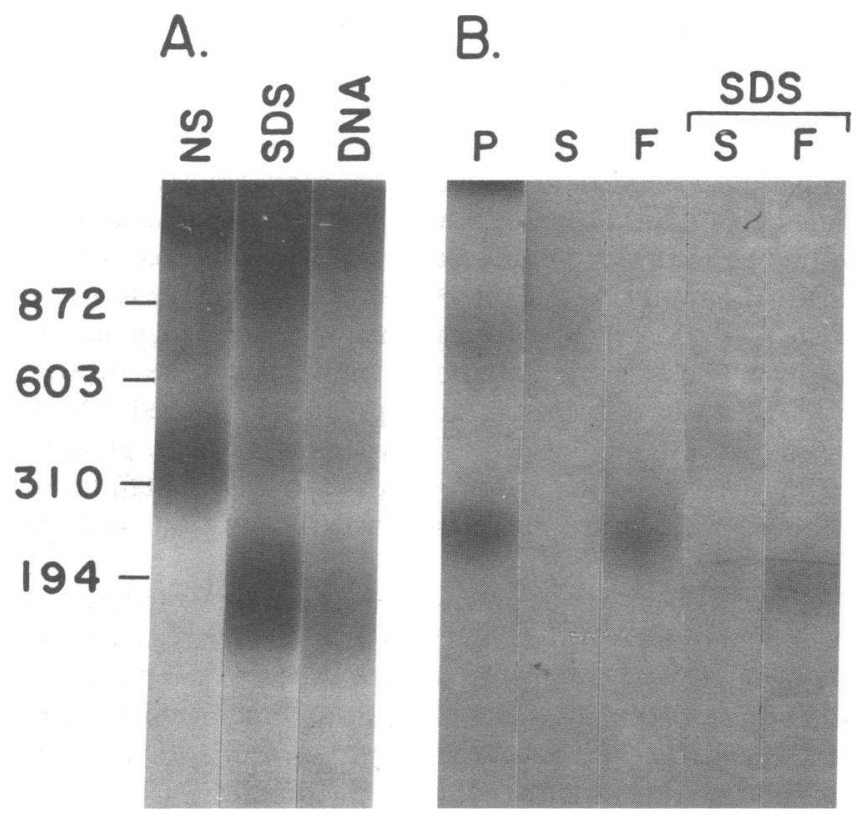

Figure 3. Autoradiographic patterns of DNA on PAGE. $(A)$ Behavior of chick ON containing labeled DNA on PAGE. As indicated at the top, the lanes contain, from left to right, ON in buffer, ON treated with SDS and DNA extracted from $O N$ and then labeled. The multiple banding pattern of ON in buffer is similar to that of DNA in plasma, but slower, at least for the fast band. Treatment of ON with SDS results in a pattern similar to that of DNA extracted from ON which shows the expected 200-bp ladder and resembles that seen in Fig. $1 \boldsymbol{B}$ for purified plasma DNA. (B) Behavior in SDS of individual plasma DNA bands. Lane $P$ contains labeled DNA in plasma $(10 \mu \mathrm{l})$, not treated with SDS. The next two lanes, $S$ and $F$, contain the excised, electroeluted slow and fast bands, respectively, again without SDS. The next two lanes, labeled SDS, contain these same slow and fast bands but after SDS treatment. The slow band yielded a predominant band at $400 \mathrm{bp}$ and a fainter band at $200 \mathrm{bp}$, identical in mobility to the single band seen after SDS treatment of the fast band, shown in the last lane at the right. Each $S$ and $F$ lane contains electroeluted and reconcentrated DNA obtained from $27 \mu \mathrm{l}$ of original plasma.

remained slower than DNA in plasma whose mobility was not consistently altered by trypsin. Treatment of ON with SDS resulted in DNA bands that migrated almost identically with bands of labeled, purified ON DNA and which exhibited the 200-bp ladder typical of ON (13). Thus, both the SDS-treated ON and their extracted DNA gave banding patterns that closely resembled those of plasma DNA.

Studies of the isolated plasma DNA bands. DNA purified from material recovered after electroelution (11) of the faster of the two major DNA bands in plasma showed it to be 150-200 bp in size. Similar experiments with the slower, fainter DNA band repeatedly failed to yield enough DNA for visualization. However, as seen in Fig. $3 \mathrm{~B}$, treatment of the separately isolated fast and slow bands with SDS, followed by repeat electrophoresis, resulted in the fast band migrating at 150-200 bp, similar to its purified DNA. The slow plasma band yielded a major band at $400 \mathrm{bp}$ and a faint band at 150-200 bp.

Detection of histone bound to DNA in plasma. In an attempt at direct identification of histones in the fast DNA band in plasma, the latter was examined, after electroelution, by 
SDS-PAGE (12). Protein staining failed to reveal a typical histone banding pattern, although these would probably have been obscured by the large amount of plasma protein present.

In an alternate approach, five radiolabeled DNA-containing plasma specimens were immunoprecipitated with either a monoclonal antihistone or with a control monoclonal antibody. The antihistone-produced precipitates contained two- to eightfold more TCA-precipitable radioactivity (range 1.7-16\% of the total TCA radioactivity in each specimen) than did the controls (Table I), a statistically significant difference $(P$ $<0.05$ ). As already noted, attempts to add labeled $\mathrm{ON}$ to plasma consistently yielded mainly large aggregates, preventing its use as a positive control. However, $\mathrm{ON}$ in buffer gave immunoprecipitation results similar to those seen with the plasma specimens.

Examination of the redissolved immunoprecipitates by electrophoresis (Fig. 4) demonstrated, in those that gave a visible signal, DNA bands corresponding in size to about 200 and $400 \mathrm{bp}$ as expected whereas little or no autoradiographic signal was seen in the corresponding areas for control precipitates. In addition a faint DNA band, corresponding to $\sim 50-100 \mathrm{bp}$ was seen both in the plasma specimens as well as in the preparation of ON. Finally, the absence of a visible $400-b p$ band in this preparation of $\mathrm{ON}$ suggested that it may have been partially degraded.

To examine the possibility that free histones, which might have been present in plasma, could have nonspecifically bound to labeled DNA thereby accounting for its precipitation by antihistone, another set of simultaneous control experiments was performed. Purified, radiolabeled DNA, $\sim 200-300$ bp long, was added to each of the same plasma and ON specimens, this time without radiolabeling the endogenous plasma-derived DNA so that all the radioactivity was contained in the added "naked" DNA. The specimens were then subjected to the same immunoprecipitation procedure. There was no significant difference $(P>0.5)$ between the radioactivity in the antihistone (mean $=909 \mathrm{cpm}$ or $0.10 \%$ of the $866,180 \mathrm{cpm}$ added) and control precipitates (mean $=794$ cpm) so that nonspecific binding of DNA by free plasma histone is an unlikely explanation for plasma DNA precipitation by antihistone.

\section{Discussion}

The present data indicate that DNA purified from SLE plasma does not exist as a continuous distribution of size species as

\section{Table I.}

\begin{tabular}{lccc}
\hline & \multicolumn{3}{c}{ TCA precipitable cpm } \\
\cline { 2 - 4 } \multicolumn{1}{c}{$\begin{array}{c}\text { Plasma } \\
\text { specimen }\end{array}$} & Total & $\begin{array}{c}\text { Antihistone } \\
\text { precipitate }\end{array}$ & $\begin{array}{c}\text { Control } \\
\text { precipitate }\end{array}$ \\
\hline Plasma 1 & 103,302 & 1,818 & 883 \\
Plasma 2 & 169,664 & 9,068 & 1,032 \\
Plasma 3 & 43,803 & 1,729 & 743 \\
Plasma 4 & 57,276 & 9,199 & 1,134 \\
Plasma 5 & 77,167 & 3,536 & 1,504 \\
Mean ( \pm SD) & & $5,070( \pm 3,779)$ & $1,059( \pm 289)$ \\
ON & $1.7 \times 10^{6}$ & 67,597 & 434
\end{tabular}

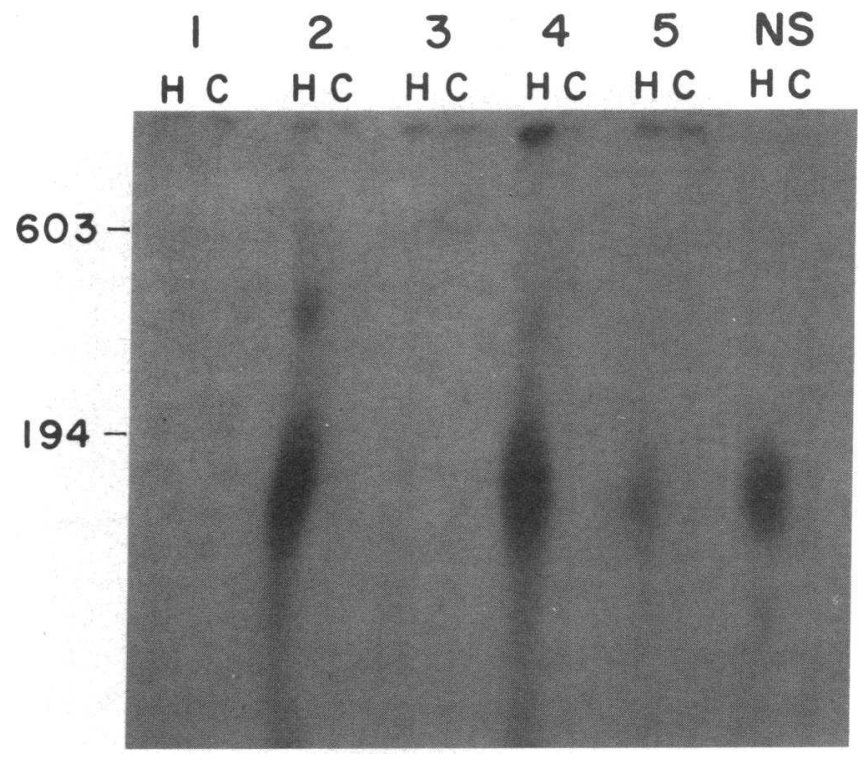

Figure 4. Radiolabeled plasma DNA after precipitation with antihistone $(H)$ or anticholinesterase control $(C)$ antibodies, after resolubilization at $100^{\circ} \mathrm{C}$ in SDS and separated on SDS-PAGE. Specimens 1-5 are derived from SLE plasmas and NS is from chick ON. The size markers are heat-denatured Hae III phi-X fragments. Lanes at the left edge of the gel are slightly distorted due to a drying artifact. In each antihistone precipitate a radioactive signal was visible on the original autoradiograph and exceeded in intensity the control signal which was generally not visible. These results were consistent with those obtained from determining the TCA-precipitable radioactivity by scintillation counting, shown in Table I.

would be expected if it consisted of randomly fragmented DNA molecules. Instead, it occurs in a series of distinct size distributions whose gel mobilities are consistent with their being derived from multimeric molecules with a unit size of $\sim 200$ bp. The largest species clearly seen was $\sim 800 \mathrm{bp}$, but small amounts of larger forms might not have been detected. These apparent multimers appear to account for most of the plasma DNA. The effects of SDS treatment and of immunoprecipitation suggest further that plasma DNA is complexed with protein that consists, at least in part, of histone.

Failure of antihistone to react with a higher proportion of plasma DNA could have resulted from either loss or inaccessibility of the trypsin-sensitive ON epitopes known to be reactive with the monoclonal antihistone antibody (14). This could have been due, for example, either to prior proteolysis or, alternatively, to blockage of the monoclonal antihistone by previously bound endogenous antihistones. Neither of these explanations was examined here.

These molecular characteristics of plasma DNA are similar to those of $\mathrm{ON}$, the structural units of chromatin, where, in each monomer, bound histone partially protects about $200 \mathrm{bp}$ of associated DNA from nuclease digestion in vitro $(13,15)$. The consequence is that DNA extracted from partially nuclease-digested chromatin exhibits a characteristic 200-bp "ladder" on electrophoresis. However, mononucleosome DNA can be further digested so that, after purification, additional molecules ranging in size from $\sim 150-200$ bp are seen. Also, several size species in the range of 50 to $110 \mathrm{bp}$ have been reported (14-16). Thus, the observed size distribution of DNA 
purified from plasma is strikingly similar to that found for $\mathrm{ON}$, both here and in the literature.

It is therefore concluded that the ON-like structure observed here for plasma DNA is consistent with its having been derived from cellular $\mathrm{ON}$ with at least partial retention of their structural features.

The electrophoretic behavior of DNA in the electroeluted fast and slow plasma bands following treatment with SDS suggests DNA contents consistent with ON-like monomers and dimers, respectively. However, this could be directly confirmed with purified DNA only for the fast band.

Whether the slow band in fact contains DNA molecules of $\sim 400$ bp depends upon the assumption that SDS treatment of the complexes in the slow band results in DNA that migrates as free molecules, a likely but unproved assumption. It thus remains possible that the ON-like mobility of DNA in whole plasma is determined by binding to plasma proteins, although this seems unlikely since, as noted, that would leave unexplained the mobilities of DNA observed after SDS treatment of the isolated slow and fast bands. It is emphasized, however, that identification of specific DNA bands seen in whole plasma with specific nucleosome-related structures, a large number of which have been described (14-16), would be premature.

Even though it appears likely that the present data are explained by an ON-like structure of plasma DNA, it is appropriate to consider alternate explanations. Although nonhistone, DNA-binding proteins are present in the nucleus (17) and could perhaps generate plasma DNA-protein complexes, they are present in much smaller amounts than histones and, further, cannot as readily explain the observed size distribution of the purified DNA. However, our current understanding of these proteins is still too rudimentary to eliminate this possibility with certainty. Similarly, neither plasma DNA binding proteins (18) nor bound anti-DNA antibodies, if present, could easily account for the observed plasma DNA size distribution. Although anti-dsDNA antibodies partially protect DNA from nucleases, the length protected is only about $40 \mathrm{bp}$ (19). Moreover, these explanations would not account for the reactivity of plasma DNA with antihistone antibody. However, these considerations do not exclude the possibility that DNA present in plasma, even in the form of ON-like complexes as postulated, might form additional bonds, either specific or nonspecific, with other plasma molecules. In this regard, it is emphasized that most SLE plasma specimens exhibiting free DNA, as found here, and as has been our general experience, do not also contain free anti-dsDNA detectable by binding assays. However, the presence of bound antibody, undetectable in this way by virtue of excess dsDNA antigen, cannot be excluded by these data but, as noted, would seem unlikely to affect the present results.

Because the study patients were selected for having large amounts of plasma DNA in association with vasculitis or CNS involvement, the extent to which these results can be generalized is uncertain. However, several previous reports $(3,5,20$, 21) of DNA isolated from plasma of SLE patients who had apparently not been selected in this manner found it to be between 100 and $200 \mathrm{bp}$ in size as is the case for the predominant species described here and thus supports the generality of these findings. In addition, one of these reports describes a 300-bp species of DNA from serum of one SLE patient (21). From the data presented it seems possible that this DNA spe- cies was the same as that considered to be $\sim 400 \mathrm{bp}$ in the present study since the $8 \%$ polyacrylamide gel used there provided less precise size discrimination in this region than does the $6 \%$ gel used here. Failure in those studies to describe larger molecular species consistent with multimeric forms as described here could have resulted from other differences in technique. For example, the use here of nick-translation, which incorporates the radiolabel throughout the DNA molecule, would be expected to enhance sensitivity of detection of longer molecules relative to shorter ones, in contrast to methods that incorporate the radiolabel only at chain termini, as employed in at least one such study. Also, failure in the present study to recognize a 17.5-kb DNA molecule, as described in another report (22), cannot be attributed to omission of proteolysis as was suggested to explain that result. It was observed here, however, that, without SDS, much of the DNA was in aggregates too large to enter the gel, as was also reported in that study. However, this could have been due to the low ionic strength of the gel buffer. Nonetheless, the possibility that a small fraction of DNA of large size eluded detection in the present study cannot be excluded.

The significance of recognizing an ON-like structure for SLE plasma DNA is severalfold. First, it is consistent with other evidence suggesting that this DNA is largely or entirely derived from DNA in the human nucleus $(4,23)$, rather than from a non-genomically integrated viral agent, for example, as has been described in at least one other clinical state (24). Second, it has been proposed that autoimmunity in SLE results from an immunogen-driven mechanism, in contrast to a less specific mechanism such as polyclonal immune activation (25). One piece of evidence for this is the reported concordance, in individual patients, of antibodies directed at molecules that occur in nature as macromolecular complexes but that otherwise appear quite different structurally (25). Antibodies to histones and DNA have been reported to occur in such "linked sets," thus suggesting that a histone-DNA macromolecular complex, presumably ON derived, might act as their common autoimmunogen. The present finding that such an extracellular histone-DNA complex does in fact occur in vivo, in SLE plasma, and, in addition, that it possesses the spectrum of DNA sizes expected of an ON-like complex is consistent with such an immunogen-driven mechanism.

In a different context, the occurrence of SLE plasma DNA in ON-like complexes implies potential autoantibody-recognition of non-DNA components of the complex $(13,26)$, which could therefore contribute to DNA-containing immune complex formation independently of anti-DNA and which might merit further study. Similarly, positively charged sites known to be present on such non-DNA components of ON (15) could allow binding to negatively charged moieties in the glomerular basement membrane and mediate formation of DNA-antiDNA immune complexes in situ as has been postulated to occur (1).

If SLE plasma DNA occurs in the form of a double supercoil of DNA tightly wound about a histone core, as is the case for $\mathrm{ON}(13,15)$, consequent structural constraints might be expected to have an important influence, difficult to predict, on its reactivity with anti-DNA antibodies and on the behavior of immune complexes so formed, as for example, in complement activation or tissue deposition, that would require further investigation of these important phenomena. Also, the possibility should be considered that antibodies might prefer- 
entially react with both of the two adjacent dsDNA strands wound about the same core, either as two separate but contiguous binding sites that might permit a form of monogamous bivalent binding (27) or, more speculatively, that the separate chains might form a single, new epitope if they were spaced closely enough.

Extracellular ON-like complexes generated in vivo do not appear to have been studied previously. Therefore, assuming it is correct that SLE plasma DNA has such a structure, it might differ in unexpected ways from ON prepared in vitro, chiefly from avian erythrocytes, which provide much of our current knowledge about these complexes (13). Such differences could be immunologically important and, in addition, might provide insight into mechanisms of their release into the circulation which is not now understood.

In this last regard, a particularly significant question is whether the ON-like structure of SLE plasma DNA is generated within an intact nucleus, a phenomenon that is a hallmark of apoptotic (in contrast to necrotic) cell death, a well-defined process that characterizes a variety of important physiologic events, including some with immunologic relevance (28).

It is uncertain whether $\mathrm{ON}$ generated during apoptosis can escape phagocytosis, with which it is closely associated, and thus gain access to the extracellular fluid, at least on a large enough scale for detection in plasma. The present data would be consistent with that possibility, however, at least in SLE. Clearly, however, much more information is needed to clarify these questions.

\section{Acknowledgments}

We wish to thank Ms. M. Lange for her technical assistance and Dr. D. Kaplan for a critical reading of the manuscript.

This work was supported in part by grants from the National Institutes of Health, The SLE Foundation, Inc. and from the New York Chapter of the Arthritis Foundation.

\section{References}

1. Zvaifler, N. Z., and V. L. Wood, Jr. 1985. Etiology and pathogenesis of systemic lupus erythematosus. In Textbook of Rheumatology. W. N. Kelly, E. D. Harris, Jr., S. Ruddy, and C. B. Sledge, editors. W. B. Saunders Co., Philadelphia, PA. 1042-1070.

2. Davis, G. L., Jr., and J. S. Davis IV. 1973. Detection of circulating DNA by counterimmunoelectrophoresis (CIE). Arthritis Rheum. 16:52-58.

3. McCoubrey-Hoyer, A., T. B. Okarma, and H. R. Holman. 1984. Partial purification and characterization of plasma DNA and its relation to disease activity in SLE. Am. J. Med. 77:23-34.

4. Steinman, C. R. 1984. Circulating DNA in systemic lupus erythematosus. Isolation and Characterization. J. Clin. Invest. 73:832841.

5. Sano, H., and C. Morimoto. 1982. DNA isolated from DNA/ anti-DNA antibody immune complexes in systemic lupus erythematosus is rich in guanine-cytosine content. J. Immunol. 128:1341-1345.

6. Raptis, L., and H. A. Menard. 1980. Quantitation and characterization of plasma DNA in normals and patients with systemic lupus erythematosus. J. Clin. Invest. 66:1391-1399.
7. Steinman, C. R. 1979. Circulating DNA in systemic lupus erythematosus. Association with central nervous system involvement and systemic vasculitis. Am. J. Med. 67:429-435.

8. Tan E. M., A. S. Cohen, J. F. Fries, A. T. Masi, D. J. McShane, N. F. Rothfield, J. G. Schaller, N. Talal, and R. J. Winchester. 1982. The 1982 revised criteria for the classification of systemic lupus erythematosus. Arthritis Rheum. 25:1271-1277.

9. Steinman, C. R. 1982. Detection and semiquantitation of DNA by counterimmunoelectrophoresis (CIE). Methods Enzymol. 84:187193.

10. Steinman, C. R., U. Deesomchok, and H. Spiera. 1976. Detection of anti-DNA antibody using synthetic antigens. Characterization and clinical significance of binding of poly(deoxyadenylate-deoxythymidylate) by serum. J. Clin. Invest. 57:1330-1341.

11. Maniatis, T., E. F. Frisch, and J. Sambrook. 1982. Molecular Cloning. A laboratory manual. Cold Spring Harbor Laboratory, Cold Spring Harbor, NY. 545 pp.

12. Goodman, M., and A. Dahlberg. 1982. Electrophoresis of nucleoproteins. In Gel Electrophoresis of Nucleic Acids, a Practical Approach. D. Rickwood and B. D. Hames, editors. IRL Press Ltd., Oxford. 199-225.

13. Kornberg, R. D. 1977. Structure of chromatin. Annu. Rev. Biochem. 46:931-954.

14. Bakayev, V. V., T. G. Bakayeva, and A. J. Varshavsky. 1977. Nucleosomes and subnucleosomes: Heterogeneity and composition. Cell. 11:619-629.

15. McGhee, J. D., and G. Felsenfeld. 1980. Nucleosome structure. Annu. Rev. Biochem. 49:1115-1156.

16. Sollner-Webb, B., R. D. Camerini-Otero, and G. Felsenfeld. 1976. Chromatin structure as probed by nucleases and proteases: evidence for the central role of histones H3 and H4. Cell. 9:179-193.

17. Lewin, B. 1983. Repressor is a dimer that binds cooperatively at each operator. In Genes. 2nd Edition. B. Lewin, editor. John Wiley and Sons, New York. 266-271.

18. Hoch, S., and E. McVey. 1977. Purification and characterization of two major DNA-binding proteins in human serum. J. Biol. Chem. 252:1881-1887.

19. Emlen, W. R., Ansari, and G. Burdick. 1984. DNA-anti-DNA immune complexes: Antibody protection of a discrete DNA fragment from DNAase digestion in vitro. J. Clin. Invest. 74:185-190.

20. Fournie, G. J. 1988. Circulating DNA and lupus nephritis. Kidney Int. 33:487-497.

21. Morimoto, C., H. Sano, T. Abe, M. Homma, and A. D. Steinberg. 1982. Correlation between clinical activity of systemic lupus erythematosus and the amounts of DNA in DNA/anti-DNA antibody immune complexes. J. Immunol. 139:1960-1965.

22. Rieber, M., C. E. Contreras, M. S. Rieber, and N. E. Bianco. 1986. Novel DNA-protein complex and a large DNA in SLE cryoprecipitates. Clin. Exp. Immunol. 66:61-67.

23. Li, J. Z., and C. R. Steinman. 1989. Plasma DNA in systemic lupus erythematosus. Arthritis Rheum. 32:726-733.

24. Hung, P. P., J. C. Mao, C. M. Ling, and L. R. Overby. 1975. Hybridization of Dane particle DNA with the free plasma DNA of hepatitis carriers. Nature (Lond.). 253:571-572.

25. Craft, J., and J. A. Hardin. 1987. Linked sets of antinuclear antibodies: What do they mean? J. Rheum. 14(Suppl.):106-109.

26. Bustin, M. 1979. Immunological approaches to chromatin and chromosome structure and function. Curr. Topics Microbiol. Immunol. 88:105-142.

27. Day, E. D. 1972. Antibody reactions with multivalent antigens. Advanced Immunochemistry. Williams and Wilkins, Baltimore, MD. 311-356.

28. Wylie, A. H. 1987. Apoptosis: Cell death in tissue regulation. $J$. Pathol. 153:313-316. 